Date of publication: March 29, 2022

DOI: 10.52270/26585561_2022_13_15_119

Economical Sciences

\title{
THEORETICAL ASPECTS OF ASSESSING THE LEVEL OF INNOVATIVE DEVELOPMENT OF THE REGION'S INDUSTRY
}

\author{
Batirova, Nilufar Sherkulovna ${ }^{1}$ \\ ${ }^{1}$ Senior lecturer, PhD in Economics, International Islamic Academy of Uzbekistan, Tashkent, \\ Uzbekistan, E-mail: nilu808@mail.ru
}

\begin{abstract}
In the modern era, regional industry is an important impulse or the main driving force of the national economy. Thanks to the expert analysis of the Organization for Economic Cooperation and Development, it is concluded that over the past decade, $50 \%$ of the economic development of Western countries primarily depends on innovation. Sustainable and efficient development of the industrial sector implies, first of all, the development of small and medium-sized businesses that stimulate the country's innovative development. In this regard, the article discusses the theoretical aspects of the level of innovation of the regional industry. A comparative analysis of the opinions of scientists on the innovative assessment of the region's industry has been carried out. In conclusion, ways were developed to ensure the innovative development of the regional industry.
\end{abstract}

Keywords: region, innovations, industry, cooperation, potential, resource, factor, assessment, comparative analysis, complex.

\section{INTRODUCTION}

At determining the innovative way of developing industrial production in the region, as well as the innovative development strategy, it is necessary to assess the resource possibilities of the region. The transformation of new scientific knowledge, ideas, discoveries, developments, as well as the improvement of existing technologies for the production of new products due to the market demand is an important issue in today's competitive environment. At the same time, industrial enterprises in the region must have an innovative potential to achieve innovative goals. 


\section{METHODOLOGY AND DISCUSSION}

Methods of structural analysis, logical thinking, economic and statistical generalization, analysis and synthesis, comparative and factor analysis, tables and graphs, econometrics and forecasting were used in the article.

According to W. Powell, a special attention should be given to the personnel issue at creating innovative capacity in industries [18]. L. Smith Dore argues that the resource factor plays a special role in assessing the innovative development of industrial enterprises, while its presence indicates strength, and its absence indicates dependence [18]. Due to S. Kochetkova's opinion [8,200], the innovative potential shows the possibility of innovative development of industrial enterprises based on their own resources. These resources include human, production and investment resources. Due to the researches of A. Nikolaeva [11,435], innovation potential is a system of factors and conditions necessary for the implementation of innovation processes. Based on the assessment of the innovative potential, the innovative possibility of the region will be assessed. In the scientific researches of O. A. Romanov, F. V. Vazagov, V. I. Zinchenko, R. E. Preobrazhensky [13,806], A. Luis, R. Solow, A. Voltes, V. N. Gunin, V. P. Barancheev, N.P. Maslennikova, V.M. Mishina [5,343], B.A. Begalova, H.T. Mukhitdinova, A.Kenjabaev $[1,124]$, from the point of view of a systematic approach to the concept of innovative potential, is defined as the level of prepareness to implement a program or project of innovative strategic change, sustainable industrial production and willingness to innovate. In the works of such scientists as $\mathrm{C}$. Cobb, P. Douglas, N. Kaldor, R. Pindyke, A. R. Bakhstizin, V. K. Zausaev, S. M. Ibatullin, V. N. Kiselev, E. C. Sadikov, E.A. Monastyrny, O.S.Moskvina, E.L. Plisetskiy, T.G. Ratkovskaya, Z.G. Sangadiev, M.V. Sivov, V. Kobulov, T. Shodiev, R. Dalimov, S. Umarov, S. Khomidov, the concept of "assessment of the innovative potential of the region" and the analysis and problems of innovative development of industry in the region can be observed. However, nowadays many unresolved issues in the theory and practice of monitoring the innovative potential of the region's industry indicate the need to study that industry. The innovative potential of the region's industry forms the basis of the region's potential, which allows it to increase its competitiveness using available resources. At assessing the innovative potential, it is necessary to study its resource, internal and effective components. In addition, at studying the structure of resources, it is necessary to assess the potential of material, technical, informational, financial and human resources (resources), government assistance and infrastructure (internal), the efficiency (effective) of the economic system.

\section{RESULTS}

The industrial development of the region has a significant impact on the socio-economic efficiency of the region. The ratios for the general parameters of industrial potential are given in different sources in different ways, in general accounting they combine the system of indicators in the Table 1 . The content of the resource is the main creative force that has a direct impact, while the internal content keeps the characteristics of the suitability and effectiveness of all elements. An effective content indicates the creation of a new product as the final result of realizing all the possibilities. The innovative potential of the region's industry consists of the accumulation of various resources and should cover the following group of indicators.

1. Financial indicators (enterprise funds, regional funds, credit and investment funds, grants, experimental and technological equipment base, resource areas). The necessity to assess financial resources for the implementation of innovative activities is occurred. The best situation is the availability of free funds that can be spent on innovative work. Taking into account the problems of regional enterprises at their own expense, the most optimal option for innovative development is their integration strategy.

2. Production potential (a leading-leader, labor resources interested in innovations, cooperation relations of the enterprise labor resource with research institutes and educational institutions, research experience, project management experience, high level of information support). G.B. Shanazarov considers, that production 
facilities are the most important component of economic potential. Production potential due to this concept includes various resources representing production assets and capacities.

3. Workforce capacity employed in the industry (high intellectual potential of employees of research and development departments (R\&D), the presence of powerful technologists at enterprises). Workforce capacity are understood as the level of qualified education of workers, the possibility of employment of the population.

4. Intellectual potential (technological documents, patents, licenses, business plans for the development of innovations, regional innovation program). Intellectual potential is considered to be a set of intellectual abilities indicating the development of knowledge, proficiency, skills, information, values and skills of workers employed in industrial enterprises, and the possibility of their implementation, development in new developments.

Table 1

Assessment of the socio-economic efficiency of the regional industrial policy $[16,32]$

\begin{tabular}{|l|l|l|}
\hline № & $\begin{array}{l}\text { Indicator of industrial } \\
\text { potential }\end{array}$ & \multicolumn{1}{|c|}{ Structures } \\
\hline 1. & Financial indicators & $\begin{array}{l}\text { Own funds } \\
\text { Borrowed funds } \\
\text { Investment funds } \\
\text { Budget funds } \\
\text { Grants }\end{array}$ \\
\hline 2. & Production indicators & $\begin{array}{l}\text { Refund } \\
\text { Production profitability } \\
\text { The level of renewal of fixed assets } \\
\text { Share of general funds in fixed assets of 10 years term }\end{array}$ \\
\hline 3. & Workforce capacity & $\begin{array}{l}\text { Qualification level of employees of industrial enterprises in the region } \\
\text { Contribution of qualified labor resources under 30 years of age } \\
\text { Contribution of labor resources involved in innovative projects } \\
\text { Wages level performing in science and technology sphere } \\
\text { Indicator of effective production management }\end{array}$ \\
\hline 5. & Market & $\begin{array}{l}\text { The share of new products in the gross industrial output of the region } \\
\text { The share of new technologies } \\
\text { The share of costs directed to R\&D due to production-oriented costs } \\
\text { Level of intellectual property ownership }\end{array}$ \\
\hline & & $\begin{array}{l}\text { Competitiveness of industrial products } \\
\text { Profitability of innovative products } \\
\text { Market share }\end{array}$ \\
\hline
\end{tabular}

In our opinion, at assessing the potential of the industrial sector of the region, it is necessary to assess the industrial enterprises of the region, which is considered as the basis of the industrial complex, based on their investment attractiveness, innovation orientation, innovation efficiency, as well as innovative activity in sequence and order (Table 2). From our point of view, ensuring the accuracy of the analysis results at the level of innovative development is based on the indicators of the financial statements of industrial enterprises. 
Assessment of the innovative potential of the region's industry in terms of investment attractiveness assumes the use of the current liquidity ratio, financial leverage, return on assets, gross profit, indicators of economic value added.

Table 2

Methodology for innovative assessment of the region's industry

\begin{tabular}{|l|l|}
\hline $\mathbf{1 .}$ & Assessment of innovative potential of industrial enterprises \\
\hline 1.1. & Analysis of the level of innovative development of industrial enterprises of the region \\
\hline 1.1 .1$. & Assessment of investment attractiveness of industrial enterprises \\
\hline 1.1 .2$. & Assessment of innovation orientation and innovation efficiency of finance of industrial enterprises \\
\hline 1.1 .3$. & Assessment of innovative activity of industrial enterprises \\
\hline 1.2. & Calculation of regional indices of industrial enterprises' innovative activity of the region \\
\hline $\mathbf{2 .}$ & $\begin{array}{l}\text { Assessment the process of organizing clusters and other types of } \text { industrial } \\
\text { complexes }\end{array}$ \\
\hline $\mathbf{3 .}$ & Analysis of the results \\
\hline
\end{tabular}

The current liquidity and financial leverage ratios indicate the financial possibilities of industrial enterprises in the implementation of innovative activities [6,134]. In order for innovations to be financed with the least risk, it is urgent to focus on the effective use of the company's equity capital in the current situation. For this purpose, an indicator of economic value added is used.

Calculation and analysis of the return on assets ratio contributes to assess the ability of an enterprise to increase capital. Enterprises whose current activities are characterized by high profitability are usually prepared for the implementation of innovative projects, which indicates the need for a gross profit ratio. An important contribution to the formation of an objective assessment of the level of innovation potential of the region's industry is the assessment of innovation orientation, as well as the effectiveness of financial investments of industrial enterprises.

The region provides for the use of ratios for assessing the innovative potential of industrial enterprises, the ratio of efficiency of investment activities, the availability of intellectual property, renewal of fixed assets, investment activity, and financing of investment development. The use of similar set of ratios allows to assess the innovation and investment potential, taking into account the investment activity of enterprises, the amount of funds aimed at renewal their property, the authorized capital and securities of another organization, the main instruments in accordance with the requirements of modern scientific and technological development.

In the process of analyzing the innovative development of industrial enterprises in the region, it is important to assess the innovative activity of the industrial network due to various types of activities, where the contribution of innovatively active enterprises to the total number of industrial enterprises is an important indicator. Ultimately, over the past three years, in the process of implementing innovative projects, it is important to transform ordinary enterprises into innovatively active enterprises. Also, the financial stability of enterprises plays a significant role. (Table 3 ).

Table 3

Assessment of the financial stability of industrial enterprises in the region $[17,55]$

\begin{tabular}{|l|l|l|}
\hline № & Indicators of financial stability & Calculation formula \\
\hline 1 & $\begin{array}{l}\text { Availability of own circulating assets of } \\
\text { industrial enterprises in the region }\end{array}$ & $\begin{array}{l}\text { Availability of own working capital = sources of private capital - } \\
\text { fixed assets and investments }\end{array}$ \\
\hline
\end{tabular}


\begin{tabular}{|l|l|}
\hline 2 & Sources of own funds and long-term
\end{tabular} borrowed funds of industrial enterprises of the region

3 The total amount of the main sources of funds for the formation of reserves and costs
Availability of own working capital and long-term borrowed funds $=$ availability of own working capital + long-term loans

The total amount of the main sources of funds for the formation of reserves and expenses = Availability of own working capital and long-term borrowed funds + short-term loans and borrowings

It is also advisable to analyze the innovative development of industrial enterprises in the region in some stages (Table 4). Technological innovation is one of the main factors in increasing labor productivity and competitiveness of the region's industry. They also participate as a factor connecting the interests of the state and entrepreneurs. Accordingly, the analysis of indicators of the share of costs allocated to technological innovation allows analyzing each observed industrial enterprise separately, in addition to assessing the innovative potential of the region. It increases the cost of analyzing the result.

The next step in assessing the innovative potential of industrial enterprises is the calculation of integral indices of the innovative potential of industrial enterprises. Where: added value in the production process (this indicator reflects the level of technological development of production, calculated by subtracting material costs from the cost of production in absolute values); the volume of investments in high-technology networks (in\%) in the total production volume; the number of high-performing jobs that have been reorganized. The aim of assessing the innovative activity of the region's industry is to increase the competitiveness of the region. The share of high-tech products to assessing the level of innovation in the region's industry is one of the important indicators.

Table 4

Stages of analysis of the level of innovative development of industrial enterprises in the region

\begin{tabular}{|c|c|}
\hline $\begin{array}{c}\text { The stage of analysis of the } \\
\text { level of innovative } \\
\text { development }\end{array}$ & Indicators used \\
\hline $\begin{array}{l}\text { Assessment of investment } \\
\text { attractiveness of industrial } \\
\text { enterprises }\end{array}$ & $\begin{array}{l}\text { current liquidity ratio } \\
\text { financial leverage ratio } \\
\text { gross profitability indicator } \\
\text { asset return ratio } \\
\text { the ratio of own funds to borrowed funds }\end{array}$ \\
\hline $\begin{array}{l}\text { Implementation of scientific and } \\
\text { research developments by } \\
\text { industry }\end{array}$ & $\begin{array}{l}\text { the volume of scientific and research developments focused on the } \\
\text { industrial sector } \\
\text { the volume of project design and technological work aimed at the } \\
\text { industrial sector } \\
\text { the volume of scientific and research developments focused on the high- } \\
\text { technology industry } \\
\text { the contribution of higher education institutions in the scientific and } \\
\text { research developments } \\
\text { age composition of people engaged in scientific research }\end{array}$ \\
\hline
\end{tabular}




\begin{tabular}{|l|l|}
\hline $\begin{array}{c}\text { Assessment of financial } \\
\text { resources aimed at innovation of } \\
\text { industrial enterprises }\end{array}$ & $\begin{array}{l}\text { the ratio of availability of intellectual property objects, number of patents } \\
\text { Industrial samples in the composition of patents } \\
\text { fixed assets renewal ratio } \\
\text { investment activity ratio } \\
\text { the share of foreign investment in the financing of innovation costs } \\
\text { government contribution to the financing of R\&D }\end{array}$ \\
\hline $\begin{array}{l}\text { Assessment of innovative activity industrial sector } \\
\text { of the }\end{array}$ & $\begin{array}{l}\text { indicator of the contribution of innovatively active enterprises by type of } \\
\text { economic activity } \\
\text { the share of industrial enterprises in the structure of innovative } \\
\text { enterprises } \\
\text { the share of enterprises producing high-tech products in the structure of } \\
\text { innovative enterprises } \\
\text { the share of innovative products in GRP } \\
\text { the share of innovative industrial products in GRP } \\
\text { the share of high-tech industrial products in GRP } \\
\text { the share of expenditures on technological innovation in GRP } \\
\text { the share of innovation costs focused on the industry } \\
\text { direction of innovative costs to the high-tech industry }\end{array}$ \\
\hline
\end{tabular}

The advantage of this indicator is that, it is a relative indicator for analysis, as well as it can be compared. According to international practice, the increase in the volume of investments directed to the high-tech sector exceeds the growth rate of GRP, which is the main condition for intensive scientific and technological development, that is, the growth rate of investments from the growth rate of GRP requires the guidance of financial support to basic innovations.

In addition to analyzing the forms of organization of the industrial complex of the region, there is a need to develop a system for assessing the level of innovative development of the industrial sector of the regions. In order to correctly assess the potential of the region, it is necessary to develop an assessment methodology taking into account quantitative and qualitative factors, as well as the innovation factor. Additionally, the necessary indicators can be divided into two. These are indicators of factors and results, which are distributed as follows (Table 5).

Due to the analysis, there are several difficulties in the implementation of the innovative development of the industrial complex. One of them is the need to properly take into account the level of financial provision and project risks at implementing innovative ideas.

Innovation processes cannot be carried out without active government regulation. Over the last few years, innovation has become an important factor in socio-economic development. The production of high-quality goods and services improves the living conditions of the population. We have studied the scientific researches of foreign and native scientists-economists such as W. Powell, L. Smith, S. Kochetkova, A. Nikolaev, V. Gunin, A. Trifilova, V. Barancheev, C. Cobb, P. Douglas, E Anchishkin, Sh.I. Mustafakulov, G.B.Shanazarova, F.Shakirova, Z.Gaibnazarova, G.Hasanova, R.Nazarova, Sh.Zaynutdinov, H.Muhitdinov, U. Gafurov, I. Umarov, we improved the factors influencing the development of the industry of the zone, and the method for assessing their quality indicators (Table 5). 
Table 5

\begin{tabular}{|c|c|c|c|c|c|c|}
\hline № & Indicator & $\begin{array}{l}\text { Type of } \\
\text { indicator }\end{array}$ & 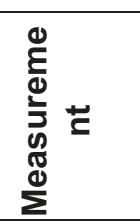 & Notes & $\begin{array}{l}\text { Bottom } \\
\text { limit }\end{array}$ & 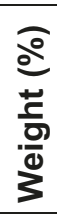 \\
\hline \multicolumn{7}{|c|}{ 1. Factorial indicators } \\
\hline \multicolumn{7}{|c|}{ 1.1. Condition of production funds } \\
\hline 1 & $\begin{array}{ll}\text { Technological } & \text { base } \\
\text { allocated to R\&D } & \end{array}$ & Quality & $\%$ & $\begin{array}{l}\text { Shows the contribution of } \\
\text { fixed assets aimed at the } \\
\text { implementation of R\&D in the } \\
\text { structure of general fixed } \\
\text { assets }\end{array}$ & $>10 \%$ & 20 \\
\hline 2 & $\begin{array}{l}\text { The level of renewal (or } \\
\text { depreciation level) of fixed } \\
\text { assets of industrial } \\
\text { enterprises }\end{array}$ & Quality & $\%$ & $\begin{array}{l}\text { Performs the level of provision } \\
\text { of industrial enterprises with } \\
\text { modern technologies }\end{array}$ & $>60 \%$ & 20 \\
\hline 3 & $\begin{array}{l}\text { The share of general funds } \\
\text { to fixed assets up to } 5 \text { years }\end{array}$ & Quantity & $\%$ & $\begin{array}{l}\text { Indicates the contribution of } \\
\text { new fixed assets }\end{array}$ & $>40 \%$ & 25 \\
\hline 4 & The ratio of inventory activity & Quality & $\%$ & $\begin{array}{l}\text { The number of patent } \\
\text { applications for an invention } \\
\text { per } 1000 \text { people of the } \\
\text { population }\end{array}$ & $>500$ & 35 \\
\hline \multicolumn{7}{|c|}{ 1.2. Labor resources } \\
\hline 5 & $\begin{array}{l}\text { Age composition of people } \\
\text { engaged in scientific } \\
\text { research by industry }\end{array}$ & Quality & $\%$ & $\begin{array}{l}\text { Contribution to the total } \\
\text { workforce of persons under } \\
\text { the age of } 35 \text { engaged in } \\
\text { scientific research by industry }\end{array}$ & $>30 \%$ & 30 \\
\hline 6 & $\begin{array}{l}\text { The contribution of engaged } \\
\text { people in R\&D in the total } \\
\text { structure of labor resources }\end{array}$ & Quality & $\%$ & $\begin{array}{l}\text { Contribution to the workforce } \\
\text { engaged in scientific research } \\
\text { in general by industry }\end{array}$ & $>30 \%$ & 30 \\
\hline 7 & $\begin{array}{l}\text { The contribution of people } \\
\text { with higher education to the } \\
\text { structure of the workforce }\end{array}$ & Quality & $\%$ & $\begin{array}{l}\text { Indicates the skill level of labor } \\
\text { resources }\end{array}$ & $>40 \%$ & 20 \\
\hline 8 & \begin{tabular}{lcr} 
Number of & students in \\
secondary & specialized and \\
higher & \multicolumn{2}{c}{ educational } \\
institutions & per $\quad 1000$ \\
inhabitants & &
\end{tabular} & Quality & amount & $\begin{array}{l}\text { Determines the level of } \\
\text { knowledge potential of the } \\
\text { region }\end{array}$ & $>600$ & 20 \\
\hline \multicolumn{6}{|c|}{ 1.3. Investment provision } & \\
\hline 9 & $\begin{array}{l}\text { Growth rate of investment } \\
\text { volume aimed at high- } \\
\text { technology sector (ratio of } \\
\text { GRP growth rate) }\end{array}$ & Quality & $\%$ & $\begin{array}{l}\text { Indicates the amount of } \\
\text { investments directed to the } \\
\text { high-tech sector }\end{array}$ & $>=100 \%$ & 20 \\
\hline
\end{tabular}




\begin{tabular}{|c|c|c|c|c|c|c|}
\hline 10 & $\begin{array}{l}\text { the share of the government } \\
\text { to the financing of R\&D }\end{array}$ & Quantity & $\%$ & $\begin{array}{l}\text { Indicates the state's attention } \\
\text { to R\&D }\end{array}$ & $>35 \%$ & 20 \\
\hline 11 & $\begin{array}{l}\text { Directing internal costs to } \\
\text { R\&D }\end{array}$ & Quantity & Сўм & $\begin{array}{l}\text { Illustrates the costs incurred to } \\
\text { improve the technology of } \\
\text { industrial enterprises }\end{array}$ & $>50 \%$ & 20 \\
\hline 12 & $\begin{array}{l}\text { The ratio of industry- } \\
\text { oriented investments to total } \\
\text { regional investments }\end{array}$ & Quality & $\%$ & $\begin{array}{lll}\text { Reflects the efficiency } & \text { of } \\
\text { investments aimed } & \text { at } \\
\text { industrial enterprises } & \end{array}$ & $>50 \%$ & 20 \\
\hline 13 & $\begin{array}{l}\text { The share of foreign } \\
\text { investment in innovation } \\
\text { costs }\end{array}$ & Quality & $\%$ & $\begin{array}{l}\text { Represents the share of } \\
\text { foreign investment in the } \\
\text { structure of innovative costs } \\
\text { sources }\end{array}$ & $>25 \%$ & 20 \\
\hline & 1.4 & Innovativ & technol & cal factor & & \\
\hline 14 & $\begin{array}{l}\text { The volume of project } \\
\text { design and technological } \\
\text { work in the industrial sector }\end{array}$ & Quality & soum & $\begin{array}{l}\text { Reflects a focus on the project } \\
\text { design work }\end{array}$ & $>10 \%$ & 8 \\
\hline 15 & $\begin{array}{l}\text { Contribution of costs aimed } \\
\text { at technological innovation }\end{array}$ & Quality & $\%$ & $\begin{array}{l}\text { Indicates the level of } \\
\text { technological costs }\end{array}$ & $>50 \%$ & 10 \\
\hline 16 & $\begin{array}{l}\text { The volume of scientific and } \\
\text { research developments } \\
\text { focused on the industrial } \\
\text { sector }\end{array}$ & Quality & $\%$ & $\begin{array}{l}\text { Shows the results of scientific } \\
\text { research on the industrial } \\
\text { sector }\end{array}$ & $>30 \%$ & 8 \\
\hline 17 & $\begin{array}{l}\text { Contribution of machinery } \\
\text { and equipment costs to the } \\
\text { cost structure of } \\
\text { technological innovation }\end{array}$ & Quantity & $\%$ & $\begin{array}{l}\text { Technological innovation } \\
\text { shows the contribution of the } \\
\text { costs of machinery and } \\
\text { equipment }\end{array}$ & $<30 \%$ & 6 \\
\hline 18 & $\begin{array}{l}\text { Contribution of costs to R\&D } \\
\text { in the structure of costs for } \\
\text { technological innovation }\end{array}$ & Quality & $\%$ & $\begin{array}{l}\text { Demonstrates the quality of } \\
\text { investment in technological } \\
\text { innovation }\end{array}$ & $>40 \%$ & 8 \\
\hline 19 & $\begin{array}{l}\text { The contribution of industrial } \\
\text { enterprises in the structure } \\
\text { of innovative enterprises }\end{array}$ & Quantity & $\%$ & $\begin{array}{l}\text { Defines the level of innovation } \\
\text { of industrial enterprises }\end{array}$ & $>35 \%$ & 6 \\
\hline 20 & $\begin{array}{l}\text { The contribution of } \\
\text { enterprises producing high- } \\
\text { technological products in the } \\
\text { structure of innovative } \\
\text { enterprises }\end{array}$ & Quality & $\%$ & $\begin{array}{l}\text { Indicates the level of } \\
\text { production of } \\
\text { technological products }\end{array}$ & $>20 \%$ & 6 \\
\hline 21 & $\begin{array}{l}\text { The performance of the } \\
\text { costs of technological } \\
\text { innovation }\end{array}$ & Quality & $\%$ & $\begin{array}{l}\text { Indicator of the contribution of } \\
\text { technological innovation costs } \\
\text { to GRP }\end{array}$ & $>2 \%$ & 5 \\
\hline 22 & $\begin{array}{ll}\text { The contribution } & \text { of } \\
\text { enterprises engaged } & \text { in } \\
\text { technological innovation } & \end{array}$ & Quality & $\%$ & $\begin{array}{l}\text { Represents the contribution of } \\
\text { enterprises implementing total } \\
\text { innovations }\end{array}$ & $>50 \%$ & 5 \\
\hline
\end{tabular}




\begin{tabular}{|c|c|c|c|c|c|c|}
\hline 23 & $\begin{array}{l}\text { The volume of scientific and } \\
\text { research developments } \\
\text { focused on high-tech } \\
\text { industries }\end{array}$ & Quality & cy̆м & $\begin{array}{l}\text { Indicates the level of } \\
\text { involvement of the enterprise } \\
\text { in scientific research in the } \\
\text { field of high technology }\end{array}$ & $>30 \%$ & 5 \\
\hline 24 & $\begin{array}{l}\text { The contribution of small } \\
\text { enterprises implementing } \\
\text { technological innovations, \% }\end{array}$ & Quality & $\%$ & $\begin{array}{l}\text { Demonstrates innovative } \\
\text { activity of small business }\end{array}$ & $>10 \%$ & 5 \\
\hline 25 & $\begin{array}{l}\text { The ratio of expenditures on } \\
\text { R\&D to GRP }\end{array}$ & Quality & $\%$ & $\begin{array}{lll}\text { Indicates the degree } & \text { of } \\
\text { significance } & \text { to } & \text { the } \\
\text { development of science } & \end{array}$ & $>3 \%$ & 4 \\
\hline \multicolumn{7}{|c|}{ 2. Performance indicator } \\
\hline 26 & $\begin{array}{l}\text { The contribution of higher } \\
\text { education institutions in the } \\
\text { production of innovative } \\
\text { products }\end{array}$ & $\begin{array}{l}\text { High } \\
\text { level }\end{array}$ & $\%$ & $\begin{array}{l}\text { Represents the contribution of } \\
\text { innovative products developed } \\
\text { on the basis of joint projects } \\
\text { with higher educational } \\
\text { institutions }\end{array}$ & $>50 \%$ & 15 \\
\hline 27 & $\begin{array}{l}\text { The share of high-tech } \\
\text { products in the structure of } \\
\text { total product }\end{array}$ & $\begin{array}{l}\text { High } \\
\text { level }\end{array}$ & $\%$ & $\begin{array}{l}\text { Indicates the volume of high- } \\
\text { tech products }\end{array}$ & $>10 \%$ & 10 \\
\hline 28 & $\begin{array}{l}\text { The contribution of } \\
\text { innovative products in the } \\
\text { structure of total product }\end{array}$ & $\begin{array}{l}\text { High } \\
\text { level }\end{array}$ & $\%$ & $\begin{array}{l}\text { Industrial products represent } \\
\text { the contribution of innovative } \\
\text { products in production }\end{array}$ & $>30 \%$ & 25 \\
\hline 29 & $\begin{array}{l}\text { Profitability ratio } \\
\text { innovative products }\end{array}$ & $\begin{array}{l}\text { High } \\
\text { level }\end{array}$ & $\%$ & $\begin{array}{l}\text { Reflects the level of } \\
\begin{array}{l}\text { profitability of } \\
\text { products }\end{array}\end{array}$ & $>30 \%$ & 15 \\
\hline
\end{tabular}

Each indicator is calculated proportionally with respect to the lower limit proposed by the author, and an index is determined (As a result of the author's calculations and expert evaluation, a limit is set). ( $\left.Y_{i}(\max )=2\right)$.

$$
Y_{i}=\frac{X_{i}}{X_{i}^{a}}
$$

Where: $\mathrm{i}-$ is the name of the indicator, $Y_{i}-\mathrm{i}$ is the result for the indicator, $X_{i}$ is the indicator of the region, $X_{i}^{a}-i-$ is the established limit of the indicator norm. The indicators in each group were weighted according to their importance in measuring industrial development (the total weight value is 100 percent). Taking into account these weights, the index indicator of the group is found by means of an average geometric estimate.

$$
I_{i}=\sqrt{\sum_{j=1}^{n} w_{j}} \sqrt{\prod_{j=1}^{n} Y_{j}^{w_{j}}}
$$

Where: $\boldsymbol{I}_{\boldsymbol{i}}$ is the index of the specified group, $w_{j}$ - is the weight of the $j$ - indicator in the $i$ structure of the group. After determining the result of the index for each group, a general index of the industrial development of 
the region will be found. In this case, weights are assigned to individual indices calculated for each group: for example, the innovation and technological factor - 30 percent, the investment proposal - 25 percent, the state of production funds - 15 percent, the productivity index - 15 percent, labor resources - 15 percent.

The cumulative result of the index for all indicators is calculated using the averaged geometric estimate.

$$
I^{\text {industry }}=\sqrt[\sum_{i=1}^{m} w_{i}]{\prod_{i=1}^{m} I_{i}^{w_{i}}}
$$

Where: $I^{\text {industry }}$ - general index of industrial development of the region, $w_{i}$ - weight of the $\boldsymbol{I}_{i}$ group index ( $i=$ from 1 to $m$ ). A "very good" situation when the result obtained as a result of calculations when assessing the industrial potential of the region and its level of innovation is within $0,8<I^{\text {industry }}<1$, in the range $0,6<I^{\text {industry }}<0,8$ is "good", in the range $0,4<I^{\text {industry }}<0,6$ is "average", it requires some changes, the industrial complex "below average" in the range $0,2<I^{\text {industry }}<0,4$ is characterized by a low level, as well as, in the range $0<I^{\text {industry }}<0,2$ it is considered that "bad" requires radical changes.

Assessment of the industrial potential of the regions and the level of its innovativeness will serve to develop regional programs for industrial development, the use of available resources will become the basis for analyzing the level of opportunities.

\section{CONCLUSION}

In conclusion, we can say that the innovative development of the region's industry should be based on science. For the innovative development of the region's industry, it is necessary to implement the following strategic goals:

- to increase the number of innovative industrial products (increasing the share of innovative products in the structure of industrial products in the gross region)

- to improve socially significant indicators measuring the standard of living of the population.

In our point of view, achieving economic growth in the strategy of innovative development of the industrial sector in the region, ensuring labor productivity and increasing capital is the crucial issue. Therefore, to ensure the innovative development of the industry, it is necessary to achieve the following goals:

- the need to improve the regulatory framework governing innovation;

- the necessity of creating new markets, that is, the market for intellectual property and innovative industrial products, to define the function of human resource management in economic processes;

- to develop information technologies and databases in all modern branches of science and various areas of innovation, to develop elements of innovation infrastructure in order to reduce the timing of scientific discoveries;

- to form a system for stimulating innovation (taxation), increasing the cost of R\&D and conducting research in high-tech industries;

- recognition of the importance of state financing in ensuring innovation activity at the early stages of the innovation process, the formation of a legal culture of the use of property rights;

- creating conditions for preserving and stimulating the creative activity of scientists, inventors and innovators, creating a system of training personnel specially trained in the field of innovation. 


\section{REFERENCE LIST}

Barancheev V. P., Maslennikova, N. P., \& Mishin, V. M. (2015). Innovation management. Pp. 124-125.

Batirova N. S. (2019). ANALYSIS OF THE INNOVATIVE LEVEL OF INDUSTRY IN THE TASHKENT REGION. Economics and Finance Vol. 12. Pp. 47-70. doi.org/10.34920/ivm.12.2019.63-70

Batirova, Nilufar Sherkulovna (2021) "Measures to Stabilize the Socio-Economic Development of Regions in a Pandemic (on the Example of the Industrial Complex of the Tashkent Region)" Journal «Bulletin SocialEconomic and Humanitarian Research», Vol. 9. Number 11. Pp. 2 - 14. doi: 10.5281/zenodo.4263353

Block, F. (2015). Innovation and the invisible hand of government. In State of innovation. Pp. 9-34.

Vazagova F.V., Kilchukov Z.H. (2015) The role of the branches of the industrial complex in the implementation of a new model of economic development. Fundamental research. Pp. 343-346.

Erohin P.V. On the category "liquidity" in economic theory. Liquidity criteria // Vestnik INZHEKON.IEconomics. 2013. No. 6 (65). Pp. 134-137

Kolmakov V. V. and Polyakova, A. G. Karpova, S. V. and Golovina, A. N. (2019). Cluster development based on competitive specialization of regions. Economy of Region, Vol. 15. Pp. 270-284. doi: 10.17059/2019$1-21$.

Kochetkova S.V., Kochetkova O.V. (2016). Model of the condition of the innovative potential of industrial enterprises. Innovations, (5 (211).

Maslennikov M. I. (2017). The technological innovations and their impact on the economy. Economy of Region. Vol. 4. Pp. 1221-1225. doi: 10.17059/2017-4-20.

Neganova V. P. and Dudnik, A. V. (2019). Openness to innovations of the regional agro-industry as a subjective factor of innovative activity. Economy of Region. Vol. 15. Pp. 880-892. doi: 10.17059/2019-3-19.

Rjapuhina V. N., \& Zarkovič A. V. (2015). Problem formiranja inovacione kulture kao faktora pozitivne inovacione klime-uloga obrazovanja. Godišnjak Učiteljskog fakulteta u Vranju, Vol. 6. Pp. 435-448.

Romanova O.A. (2018) Priorities of Russia's Industrial Policy in the context of the Challenges of the Fourth Industrial Revolution. The economy of the region. Vol. 14. Pp. 806-819.

Rastvortseva S.N. An innovative way of changing the trajectory of the previous development of the region's economy // Economy of the region. 2020. -T.16, Issue $1-$ p. 28-42; Romanova O.A. Priorities of Russia's industrial policy in the context of the challenges of the fourth industrial revolution. Part 2. // Economy of the region. - 2018 .-- Vol. 14, №. 3. Pp. 806-819.

Soluttseva S.N. (2020) An innovative way to change the trajectory of the previous development of the region's economy. Economy of the region. Vol. 16. Pp. 28-42. 42.

Soluttseva, S. (2020) Socio-economic problems of the region. The economy of the region. Vol. 1. Pp. 28-

Safina A.I. Methodology for assessing the socio-economic efficiency of regional industrial policy [Text] / A.I. Safina. // Expert. - 2009. №. 14. Pp. 32-37.

Trifilova A.A. Evaluation of the effectiveness of innovative development of the enterprise / A.A. Trifilova. M .: Finance and Statistics, 2005.

https://cyberleninka.ru/article/n/seti-i-hozyaystvennaya-zhizn 


\title{
ТЕОРЕТИЧЕСКИЕ АСПЕКТЫ ОЦЕНКИ УРОВНЯ ИННОВАЦИОННОГО РАЗВИТИЯ ПРОМЫШЛЕННОСТИ РЕГИОНА
}

\author{
Батирова Нилуфар Шеркуловна ${ }^{1}$ \\ ${ }^{1}$ Старший преподаватель, доктор философии по экономике, Международная исламская \\ академия Узбекистана, Ташкент, Узбекистан, E-mail: nilu808@mail.ru
}

\begin{abstract}
Аннотация
В современную эпоху региональная промышленность является важным импульсом или главной движущей силой национальной экономики. Благодаря экспертному анализу Организации экономического сотрудничества и развития делается вывод о том, что за последнее десятилетие $50 \%$ экономического развития западных стран в первую очередь зависит от инноваций. Устойчивое и эфрфективное развитие промышленного сектора подразумевает, прежде всего, развитие малого и среднего бизнеса, стимулирующего инновационное развитие страны. В связи с этим в статье рассматриваются теоретические аспекты уровня инновационности региональной промышленности. Проведен сравнительный анализ мнений ученых об инновационной оценке промышленности региона. В заключение были разработаны пути обеспечения инновационного развития региональной промышленности.
\end{abstract}

Ключевые слова: регион, инновации, промышленность, кооперация, потенциал, ресурс, фактор, оценка, сравнительный анализ, комплекс.

\section{СПИСОК ЛИТЕРАТУРЫ}

Barancheev V. P., Maslennikova, N. P., \& Mishin, V. M. (2015). Innovation management. Pp. 124-125.

Batirova N. S. (2019). ANALYSIS OF THE INNOVATIVE LEVEL OF INDUSTRY IN THE TASHKENT REGION. Economics and Finance Vol. 12. Pp. 47-70. doi.org/10.34920/ivm.12.2019.63-70

Batirova, Nilufar Sherkulovna (2021) "Measures to Stabilize the Socio-Economic Development of Regions in a Pandemic (on the Example of the Industrial Complex of the Tashkent Region)" Journal «Bulletin SocialEconomic and Humanitarian Research», Vol. 9. Number 11. Pp. 2 - 14. doi: 10.5281/zenodo.4263353

Block, F. (2015). Innovation and the invisible hand of government. In State of innovation. Pp. 9-34.

Vazagova F.V., Kilchukov Z.H. (2015) The role of the branches of the industrial complex in the implementation of a new model of economic development. Fundamental research. Pp. 343-346.

Erohin P.V. On the category "liquidity" in economic theory. Liquidity criteria // Vestnik INZHEKON.IEconomics. 2013. No. 6 (65). Pp. 134-137

Kolmakov V. V. and Polyakova, A. G. Karpova, S. V. and Golovina, A. N. (2019). Cluster development based on competitive specialization of regions. Economy of Region, Vol. 15. Pp. 270-284. doi: 10.17059/2019$1-21$. 
Kochetkova S.V., Kochetkova O.V. (2016). Model of the condition of the innovative potential of industrial enterprises. Innovations, (5 (211).

Maslennikov M. I. (2017). The technological innovations and their impact on the economy. Economy of Region. Vol. 4. Pp. 1221-1225. doi: 10.17059/2017-4-20.

Neganova V. P. and Dudnik, A. V. (2019). Openness to innovations of the regional agro-industry as a subjective factor of innovative activity. Economy of Region. Vol. 15. Pp. 880-892. doi: 10.17059/2019-3-19.

Rjapuhina V. N., \& Zarkovič A. V. (2015). Problem formiranja inovacione kulture kao faktora pozitivne inovacione klime-uloga obrazovanja. Godišnjak Učiteljskog fakulteta u Vranju, Vol. 6. Pp. 435-448.

Romanova O.A. (2018) Priorities of Russia's Industrial Policy in the context of the Challenges of the Fourth Industrial Revolution. The economy of the region. Vol. 14. Pp. 806-819.

Rastvortseva S.N. An innovative way of changing the trajectory of the previous development of the region's economy // Economy of the region. 2020. -T.16, Issue 1 -p. 28-42; Romanova O.A. Priorities of Russia's industrial policy in the context of the challenges of the fourth industrial revolution. Part 2. // Economy of the region. - 2018 .-- Vol. 14, №. 3. Pp. 806-819

Soluttseva S.N. (2020) An innovative way to change the trajectory of the previous development of the region's economy. Economy of the region. Vol. 16. Pp. 28-42.

Soluttseva, S. (2020) Socio-economic problems of the region. The economy of the region. Vol. 1. Pp. 2842.

Safina A.I. Methodology for assessing the socio-economic efficiency of regional industrial policy [Text] / A.I. Safina. // Expert. - 2009. №. 14. Pp. 32-37.

Trifilova A.A. Evaluation of the effectiveness of innovative development of the enterprise / A.A. Trifilova. M .: Finance and Statistics, 2005.

https://cyberleninka.ru/article/n/seti-i-hozyaystvennaya-zhizn 